\title{
DIGITAL TRANSITION OF TEACHING LEARNING RESOURCES AT SPANISH UNIVERSITIES
}

\section{Transición digital de los recursos informativos docentes en la universidad española}

\author{
Blanca Rodríguez-Bravo, Ana-Reyes Pacios, Marina Vianello-Osti, Manuela \\ Moro-Cabero and Marta De-la-Mano-González
}

Nota: Este artículo puede leerse traducido al español en:

http://recyt.fecyt.es/index.php/EPI/article/view/41710/23775

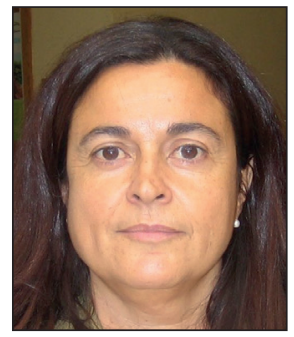

Blanca Rodríguez-Bravo, PhD in philosophy from the University of Leon, Spain, is currently associate professor of library and information science at the Department of Documentary and Cultural Heritage of the University of Leon, where she is chair of the Condor Group (Organizing and use of contents), which conducts research on knowledge organization, collections development, and usage of electronic journals. She teaches courses on authority control, knowledge organization, and scientific communication. She is the author of three monographs and co-author of another 10. In addition, she has around 60 articles in international and national journals. She has been head of 10 research projects and has participated in another 6 .

http://orcid.org/0000-0002-9476-7602

Universidad de León, Facultad de Filosofía y Letras Departamento de Patrimonio Artístico y Documental, Área de Biblioteconomía y Documentación Campus de Vegazana, s/n. 24071 León, Spain blanca.rodriguez@unileon.es

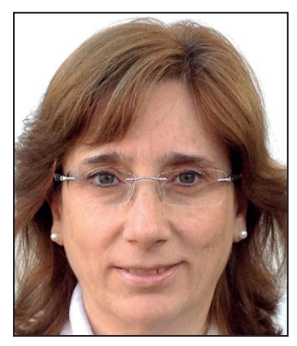

Ana-Reyes Pacios is associate professor at the Library and Information Science and Documentation Department of Carlos III University, Madrid, since 1992. Teaches library management, resource management (human, library collection, financial, and economics), direction and management techniques and other related subjects in courses leading to a degree, master, and PhD in library and documentation sciences. Her main line of research is management functions and techniques as applied to libraries (evaluation, quality, planning, and marketing). Author and co-author of various works published in both national and international librarianship journals (Library management, Library review, Libri, The electronic library, Interlending \& document supply, Performance measurement and metrics, etc.). She is a member of the University Library Commission (19942015).

http://orcid.org/0000-0003-2887-882X

Universidad Carlos III de Madrid, Departamento de Biblioteconomía y Documentación Madrid, 126-128. 28903 Getafe (Madrid), Spain areyes@bib.uc3m.es

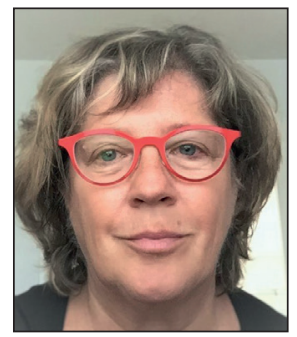

Marina Vianello-Osti is bachelor of lettere italiane by Foscari University of Venice, in philology from the Complutense University of Madrid and PhD in documentation from the Carlos III University of Madrid (UC3M). She has been responsible for the documentation centre of the Institute of Demography (CSIC). Since 1996 she has belonged to the Department of Library and Information Science at the UC3M where she currently teaches courses in history and document analysis, and description of the ancient book. Her research focuses on history of literacy, knowledge organization, content analysis, hypertext, and usability. She has participated in conferences and has publications in journals and monographs.

http://orcid.org/0000-0002-8745-3947

Universidad Carlos III de Madrid, Departamento de Biblioteconomía y Documentación Madrid, 126-128. 28903 Getafe (Madrid), Spain mvianell@bib.uc3m.es

Manuscript received on 16-07-2015

Accepted on 06-09-2015 


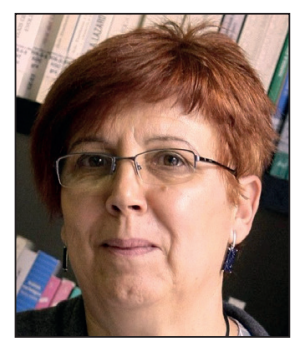

Manuela Moro-Cabero gained her PhD from the University of Salamanca in the area of records management. She is a member of CTN 50 at the Spanish standardization agency Aenor. Her recent publications deal with the dissemination of standards in Spain, and the analysis of relations of ISO series MSS. She is a member of the Observatory of Futurology Archival Science and Society of UC3M. http://orcid.org/0000-0001-5301-1924

Universidad de Salamanca, Facultad de Traducción y Documentación Departamento de Biblioteconomía y Documentación Francisco Vitoria, 6-16. 37008 Salamanca, Spain moroca@usal.es

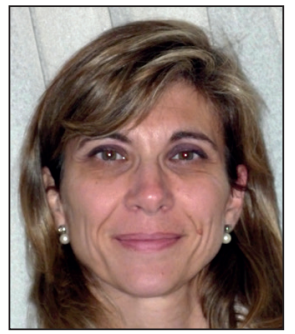

Marta De-la-Mano-González a associate professor in the Department of Library and Information Science, University of Salamanca, Spain, since 1996. Member of the ISO international working groups on Quality measures for national libraries (ISO/TC46/SC8/WG7) and on Methods and procedures for assessing the impact of libraries (ISO/TC46/SC8/WG10) as the Spanish expert. Member of the Technical Committee 50 on Information of the Spanish Association for Standardization and Certification (Aenor, AEN/CTN 50). Academic visitor in the Department of Information Science, Loughborough University, UK, from September to December 2011. http://orcid.org/0000-0002-3945-9324

Universidad de Salamanca, Facultad de Traducción y Documentación Departamento de Biblioteconomía y Documentación Francisco Vitoria, 6-16. 37007 Salamanca, Spain lamano@usal.es

\section{Abstract}

The objective of this study is to establish which document types are considered essential for learning at universities and, therefore, are recommended to students. Additionally, an analysis was conducted to determine if electronic resources are a part of the recommended reading lists for the various subjects across the curriculum and what exactly their weight is in relation to other document types. The current syllabi for the 2014-2015 academic year were accessed for each subject in ten majors offered at three Spanish universities: University Carlos III of Madrid, University of León, and University of Salamanca. The primary finding is the lack of homogeneity in the number of references by university and major which is due to the disparity observed as far as the number of references per subject. Books are the resources most frequently suggested in all of the curricula analyzed. The scarce use in course syllabi of journal articles and, particularly, conference papers, is significant. Links to institutional websites predominate, whereas the presence of electronic books is residual despite a proven inclination to prioritize recommendations for monographs and textbooks. The presence of electronic journals and electronic articles is also marginal. It is evident that traditional document types continue to be recommended despite the increase of electronic documents in academic libraries' collections.

\section{Keywords}

Academic libraries; Bibliographic references; Collection development; Collection use; Electronic resources; Mayors; Spain; Syllabi; Teaching-learning resources; University Carlos III of Madrid; University of León; University of Salamanca; University libraries.

\section{Resumen}

Se establecen qué tipos documentales son considerados esenciales para el aprendizaje en las universidades y, por tanto, son recomendados a los estudiantes. Asimismo, se analiza si los recursos electrónicos forman parte de las bibliografías de las asignaturas y cuál es su peso en relación a otros tipos documentales. Se accedió a las fichas docentes del curso $2014-2015$ de las asignaturas de diez grados ofertados en común por tres universidades españolas: Universidad Carlos III de Madrid, Universidad de León y Universidad de Salamanca. Los resultados muestran falta de homogeneidad en el número de referencias entre las universidades y entre los grados, que obedece a la disparidad observada en el número de referencias que incluyen las asignaturas. Se constata que los libros son el recurso más frecuentemente recomendado en todos los curricula analizados. Es digna de mención la escasez de artículos de revista y, especialmente, de ponencias y comunicaciones en actas de congresos. Con respecto a los recursos electrónicos, predominan los enlaces a webs institucionales mientras que la presencia de libros electrónicos es residual pese a la inclinación constatada a priorizar la recomendación de monografías y manuales. La presencia de revistas y artículos electrónicos es también marginal. Resulta evidente que continúan siendo recomendados los tipos de documentos tradicionales a pesar del incremento de los documentos electrónicos en las colecciones de las bibliotecas universitarias.

\section{Palabras clave}

Bibliografía recomendada; Bibliotecas universitarias; Desarrollo de la colección; España; Fichas docentes; Grados universitarios; Recursos electrónicos; Recursos para la enseñanza y el aprendizaje; Universidad Carlos III de Madrid; Universidad de León; Universidad de Salamanca; Uso de la colección. 
Rodríguez-Bravo, Blanca; Pacios, Ana-Reyes; Vianello-Osti, Marina; Moro-Cabero, Manuela; De-la-Mano-González, Marta (2015). "Digital transition of teaching-learning resources at Spanish universities". El profesional de la información, v. 24, n. 6, pp. 737-748

http://dx.doi.org/10.3145/epi.2015.nov.05

\section{Introduction}

The purpose of this study is to research the type of reference sources faculty believe are essential to the teaching-learning process and, therefore, recommend to their students. The aim is to use indirect methods to analyze the various types of documents both faculty and students use in education by means of an analysis of their recommended reading lists.

As Shirkey (2011) points out, conducting a syllabus study is a user-centered method that can yield benefits for the collection, the librarian, and the library as a whole. However, as she said, only three articles discuss the use of syllabi in collection development (Anderson, 1988; McDonald; Micikas, 1990; Austenfeld, 2009).

\section{Establishing the variety and distribution of referenced documents is highly useful to academic libraries which must find a balance in their collections}

This paper is focused on the user and the collection, trying to assess its balance. It's an analytical approximation to the teaching resources recommended to students using data from three Spanish universities of different sizes and belonging to two regions. The University of Salamanca (USAL) is a large university which had 25,150 students during the 2014-2015 academic year. The University of León (ULE) and the University Carlos III of Madrid (UC3M) are two mediumsized universities with 13,400 and 18,900 students, respectively.

Establishing the variety and distribution of referenced documents is highly useful to academic libraries which must find a balance in their collections among the various sources and assign a budget to each document type based on how they are used (Urbano, 2000), mainly as we are in a period of economic restrictions (Hernández-Sánchez; ArroyoVázquez, 2014; Gómez-Yáñez, 2014).

In addition, the works comprising course syllabi must be accessible at universities and should be used by librarians for guidance when building collections. Judging by the data available in the most recent Rebiun -the Spanish university library network, Red de Bibliotecas Universitarias Españolas- annual, which corresponds to the year $2012^{1}$, academic library collections still reflect a predominance of traditional format resources, mainly books, textbooks, and specialized monographs.

The circulation data available at the University of Leon show that paper books are of priority use by all sectors of the university community, but mostly by students. This situation is related to the fact that textbooks and monographs are the bibliographic materials most often recommended in syllabi, as was observed in this study, and still comprise a significant part of collections ${ }^{2}$. In the case of the USAL, $82.74 \%$ of the collection is comprised of monographs. This percentage is $85.75 \%$ at the ULE and $90.97 \%$ at the UC3M.

Nonetheless, there has been a change in process in these first two decades of the century with a gradual transition towards the electronic format. As part of regional consortiums, Spanish university libraries had contracts with the main electronic journal packages available on the market between 2001 and 2006: Emerald, ScienceDirect, SpringerLink, Wiley InterScience, etc. Their distributors are the major publishing monopolies: MCB University Press, Elsevier, Springer, Wiley \& Sons, etc.

Along with the main electronic journal packages, Spanish libraries have also subscribed in recent years to e-book collections thought to theoretically replace printed books. However, e-books have not proved to be very successful (Anglada, 2012; Long; Schonfeld, 2014).

As per Rebiun data, expenditures in Spain on electronic information has grown despite the budget cutbacks experienced by libraries. $\mathbf{5 6 . 7}$ million euro were spent in 2008 on electronic information and 72.7 million euro in 2012, out of a total procurement budget of 115.4 million euro. In other words, $62 \%$ of the total 2012 budget was invested in electronic resources.

The literature firmly establishes that intensive use of the different scientific communication vehicles varies from one scientific field to another. Knowledge is primarily disseminated in experimental science through journals. On the contrary, the use of monographs is predominant in the social sciences and humanities. The value of textbooks is quite remarkable in technical sciences.

\section{Academic library collections still reflect a predominance of traditional format resources, mainly books, textbooks, and specialized monographs}

However, Hosewright, Schonfeld and Wulfson (2013b) have indicated that the preference in the United Kingdom for peer-reviewed journals is not limited to the pure and experimental science fields. Likewise, preprint articles from peer-reviewed journals and research monographs or volumes published by academic publishers are considered important to research by UK academics although their weight differs depending on the discipline.

The data obtained from our analyses of downloads, log files, and surveys confirm that scientists in the areas of natural and health sciences are the most enthusiastic and regular users of electronic journals. The reasons for this reside in the trust they have in journals and the extensive availability 
of electronic content through their institutions, given that experimental science journals dominate the major multidisciplinary big deals. However, e-journals have been popular in other contexts such as between scholars from technical and social areas (Rodríguez-Bravo; Alvite-Díez, 2006; Rodríguez-Bravo; Melo; Costa, 2014).

Scientists in the areas of natural and health sciences are the most enthusiastic and regular users of electronic journals

Findings from surveys researching the how and why of electronic information consumption prove that the priority use of electronic journals is oriented towards research-related tasks. One example of this is the work of Tenopir and King (2000) who indicate that $75 \%$ of all users have a preference for ejournals for research purposes as opposed to the $41 \%$ who mention teaching purposes. Dilek-Kayaoglu (2008) situates this research priority at $67.5 \%$. This situation has been confirmed at one of the universities subject of the analysis in this research work - the University of Leon - as well as at Portuguese universities (Rodríguez-Bravo et al., 2013).

As for information resources for teaching purposes, surveys conducted in the United Kingdom and the USA, as gathered by Ithaka $S+R$ reports (Hosewright; Schonfeld; Wulfson, 2013a; 2013b), indicate that the most common types of sources used in teaching are textbooks and specialized monographs. More than $90 \%$ of those surveyed stated they recommend the use of textbooks and specialized monographs to students in the first two years of their degree programs and $75 \%$ of them said they did so frequently. In the case of third and fourth-year students, the percentage slightly decreased to below $90 \%$. The interdisciplinary differences observed in this study are minimal although textbooks are used more in science fields and less so in the humanities.

The cited studies also make it clear that textbooks, journal articles, and monographs are often recommended to students and at a frequency that is somewhat higher in the last two years of degree programs at 9 out of every 10 versus the 8 out of every 10 recorded for the first two years. The practice of directing students to academic articles for reference reading is substantially less common in science fields than in other fields, especially in the first two years of a program. In the areas of arts and humanities, a large portion of those surveyed indicated they habitually recommended monographs and chapters of monographs mainly to students in the last two years of a program. This practice is less common in experimental sciences.

As for audiovisual materials, only 4 out of every 10 surveytakers included them in their recommendations and only $25 \%$ confirmed they recommend reading non-academic books. These types of sources are more frequently used in the humanities and social sciences, as per data gathered at universities in the U.S. (Hosewright; Schonfeld; Wulfson, 2013a).

These data suggest priority is given to books in teaching, which has been confirmed by the collection circulation figures at the University of Leon. Moreover, the download data for this same university shows a significant increase in electronic information consumption in 2014 when compared to prior years. The most significant increase is observed in the consumption of electronic chapters and books which was fostered by the 2014 expansion of the collection with the subscription of Springer books (ULE, 2014).

The data obtained from this study were contrasted with prior work such as that by Prieto-Paíno (2013) which analyzed various aspects of the recommended reading lists given to students at the University of Salamanca for six different majors during the 2012-2013 academic year. Only one of the majors studied is included in our work. Likewise, studies done prior to the implementation of the current undergraduate degree programs on this topic focused on two specific majors -the associate's degree in library science and documentation and the bachelor's degree in documentation- were taken into consideration (Lascuráin-Sánchez; Iribarren-Maestro; Sanz-Casado, 2008).

There is a need to diversify the document types in syllaby and to increase the presence of electronic resources that are openly accessible and subscribed to by the libraries

\section{Objectives and methodology}

The general objective of this study is to establish which document types are considered essential for learning and, therefore, are recommended to students. The objective is also to determine whether electronic resources are a part of the recommended reading lists for the different subjects in the curriculum offered at three Spanish universities and what exactly their weight is in relation to other document types.

This information is available in the syllabi which are accessible to students before registering and throughout the academic year. Exploring syllabi is a simple way to obtain data and it is non-intrusive because it does not require the cooperation of the faculty.

Reviewing all of the recommended reading lists for the various undergraduate degree programs chosen for this research also allowed for the establishment of other specific objectives within this general framework as listed below:

- Identifying possible trends in the number of references included in the recommended reading lists

- Establishing the importance given to each one of the document types recommended for learning: monographs, journals, journal articles, papers, websites, and other electronic resources.

- Determining the similarities and differences in the recommended reading lists among social and technical science programs and among the universities studied.

- Identifying the beginning and ending publishing dates of the resources recommended in order to assess the period of validity faculty deem appropriate for certain materials. - Analyzing the adequacy of the bibliographic references in the reading lists. 
With this purpose in mind, the current syllabi for the 2014-2015 academic year were accessed for each subject in the 10 majors offered at three Spanish universities, the University Carlos III of Madrid (UC3M), the University of León (ULE), and the University of Salamanca (USAL).

The majors chosen are those that are common to the three universities. Five of them belong to the social science field and the other five to the technical science field. They are: bachelor's in business management, bachelor's in law, bachelor's in economics, bachelor's in information science, bachelor's in human resources, bachelor's in electrical engineering, bachelor's in electronic and industrial engineering and automatic control, bachelor's in energy engineering, bachelor's in computer engineering, and bachelor's in mechanical engineering. It is worth noting that the names coincide for most of the degree programs at the universities analyzed except for a few minor differences.

This number of majors is enough to identify a few trends. Table 1 shows the raw data and percentages with respect to all of the degree programs offered at each one of the universities as well as the representativeness out of the ensemble analyzed.

As shown in table 1 , the research involved a total of $10 \mathrm{si}-$ milar majors at each one of the universities out of a total of 131 degree programs. This data represents $22.9 \%$ of the total majors, without considering double major programs or majors offered jointly by more than one campus. The results of the sample analyzed individually denote acceptable representativeness for the UC3M at more than $30 \%$, moderate representativeness for the ULE given that it does not reach $30 \%$, and a positive trend in the case of the USAL. Considering the sum of the representativeness percentage data for each university, the average obtained for the entire sample was $25.8 \%$.

All of the bachelor's degree programs are taught over 4 academic years with 8 semesters. For the first two years, the number of subjects is rather homogeneous. However, this homogeneity is somewhat lower in the last two years since electives are added which may be more or fewer in number and, in some cases they are common to the last two years. Furthermore, there are majors with several paths and minors which also lead to an increase in the number of subjects.

The syllabus for each subject constitutes a commitment by the university to the students during the academic year and outlines the basic information for each one as relates to: the objectives sought, the content of the program, the competencies and skills the student should acquire, the evaluation system, and recommended reading list. Some subjects were excluded from this analysis: practicums; end-of-degree research work; and humanities, in the case of the University Carlos III. This decision was due to the special characteristics of each: their eminently practical nature and the possibility of researching any topic, for the first two; and, in the case of humanities, because it is a non-specific common educational complement for each major. Given these characteristics, none of them usually include a recommended reading list.

It is important to note that the syllabi that we have studied at three universities make a distinction between the core reading list and the supplementary reading list; however, the count and analysis completed does not provide for this distinction as we observed it was not use in a consistent way.

The primary finding is the lack of homogeneity in the number of references by university and major

The situation at the three universities is diverse. There is a single syllabus at the UC3M per major, irrespective of the groups taught. This situation differs in the case of the USAL for the bachelor's in law as there are 3 different paths and each group has its own syllabus with an increase in the number of subjects for this major.

The following indicators were used for the analysis presented in this study:

- Total references per major and university and relative data based on the number of subjects.

- The percentage of the presence of each document type recommended for teaching.

- The presence and weight of electronic documents.

- The age and/or recentness of the references.

- The suitability of the references in facilitating the identification and location of the sources.

\section{Results and discussion}

The primary finding is the lack of homogeneity in the number of references by university and major which is due to the disparity observed as far as the number of references per subject. This is possibly the result of a lack of recommendations by universities as to the number and form of citation. Likewise, the use of textbooks and specialized monographs above any other type of resource stands out and is emphasized bythe low presence of electronic resources.

The main findings for each one of the indicators analyzed shall now be discussed. 
Table 2. Total references by major and university

\begin{tabular}{|l|c|c|c|c|}
\hline \multirow{2}{*}{ Majors } & \multicolumn{4}{c|}{ Universities } \\
\cline { 2 - 5 } & UC3M & ULE & USAL & Total \\
\hline Business management & 336 & 717 & 552 & 1,605 \\
\hline Law & 722 & 618 & 954 & 2,294 \\
\hline Economics & 368 & 591 & 355 & 1,314 \\
\hline Information science & 549 & 504 & 793 & 1,846 \\
\hline Human resources & 348 & 982 & 610 & 2,993 \\
\hline Electrical engineering & 229 & 344 & 386 & 959 \\
\hline Electronic and industrial engi- & 281 & 447 & 374 & 1,102 \\
\hline neering and automatic control & 114 & 333 & 446 & 893 \\
\hline Energy engineering & 610 & 376 & 316 & 1,302 \\
\hline Computer engineering & 252 & 417 & 603 & 1,272 \\
\hline Mechanical engineering & 3,809 & 5,329 & 5,389 & 15,580 \\
\hline Total & & & & \\
\hline
\end{tabular}

social science majors than technical science majors.

There's the particular case of the bachelor's in information science at the USAL, for example. According to Prieto's analysis (2013), the number of references for this degree program totaled 573 in the 2012-2013 academic year. Two years later, these references increased to 793 .

Table 3 below shows a disparity in the number of bibliographic references by subject among the universities studied as the average number of references per major at the ULE practically doubles that of the UC3M. Moreover, it confirms that the number of bibliographic references is

\subsection{Total references per major and university and re- lative data based on the number of subjects}

Table 2 reflects the diversity indicated. The column that totals the number of bibliographic references by university shows that recommended reading lists are more extensive at the University of León and University of Salamanca than at the University Carlos III of Madrid, with more than 900 social science references in some social sciences majors at the first two.

The fact that University Carlos III has less extensive recommended reading lists may be due to the procedure for including the reading lists in their syllabi being conditioned by the limited size of the database field where they are entered. On the contrary, faculty at the other two universities have no limit on the size of their reading lists and may even copy and paste them from other documents.

Although the data by major do not prove consistent, they do allow for the observation that reading lists are longer for higher for social science majors except in the case of the bachelor's in economics offered by the USAL. At the UC3M, the bachelor's in computer engineering is at the same level as economics and human resources.

\section{Reading lists are longer for social science majors than technical science majors}

Only three majors exceed the average of 6.57 at the UC3M. This is the case of law, information science, and computer engineering. The number of references for the bachelor's in information science stands out at both this university and the USAL. Besides the bachelor's program mentioned, there are another three majors in Salamanca above the average (10.14): law, human resources, and mechanical engineering.

As for the ULE, all of the social science majors exceed the average of 12.02, with the human resources major showing

Table 3. References average by major and university

\begin{tabular}{|c|c|c|c|c|c|c|}
\hline \multirow{3}{*}{ Majors } & \multicolumn{6}{|c|}{ Universities } \\
\hline & \multicolumn{2}{|c|}{ UC3M } & \multicolumn{2}{|c|}{ ULE } & \multicolumn{2}{|c|}{ USAL } \\
\hline & Subjects & $\begin{array}{c}\text { References } \\
\text { average }\end{array}$ & Subjects & $\begin{array}{l}\text { References } \\
\text { average }\end{array}$ & Subjects & $\begin{array}{c}\text { References } \\
\text { average }\end{array}$ \\
\hline Business management & 58 & 5.79 & 43 & 16.67 & 58 & 9.51 \\
\hline Law & 75 & 9.62 & 48 & 12.87 & 79 & 12.07 \\
\hline Economics & 60 & 6.13 & 47 & 12.57 & 52 & 6.82 \\
\hline Information science & 42 & 13.07 & 40 & 12.60 & 46 & 17.23 \\
\hline Human resources & 54 & 6.44 & 53 & 18.52 & 54 & 11.29 \\
\hline Electrical engineering & 46 & 4.97 & $32^{*}$ & 10.75 & 47 & 8.21 \\
\hline $\begin{array}{l}\text { Electronic and industrial engineering and automatic } \\
\text { control }\end{array}$ & 57 & 4.92 & 44 & 10.15 & 45 & 8.31 \\
\hline Energy engineering & 37 & 3.08 & 42 & 7.92 & 50 & 8.92 \\
\hline Computer engineering & $89^{* *}$ & 6.85 & 43 & 8.74 & 42 & 7.52 \\
\hline Mechanical engineering & 52 & 4.84 & 44 & 9.47 & 52 & 11.59 \\
\hline Average & -- & 6.57 & -- & 12.02 & -- & 10.14 \\
\hline
\end{tabular}

*The last year of the bachelor's in electrical engineering program has not yet been offered in León.

**Three paths in the $3^{\text {rd }}$ and $4^{\text {th }}$ years. 
Table 4. Subjects without a recommended reading list by major and university

\begin{tabular}{|l|r|r|c|}
\hline \multicolumn{1}{|c|}{ Majors } & UC3M & ULE & USAL \\
\hline Business management & 8 & 2 & 2 \\
\hline Law & 12 & 4 & 2 \\
\hline Economics & 12 & 2 & 1 \\
\hline Information science & 1 & 1 & 3 \\
\hline Human resources & 12 & 3 & 1 \\
\hline Electrical engineering & 6 & 1 & 0 \\
\hline $\begin{array}{l}\text { Electronic and industrial engi- } \\
\text { neering and automatic control }\end{array}$ & 9 & 2 & 0 \\
\hline Energy engineering & 18 & 3 & 0 \\
\hline Computer engineering & 1 & 0 & 1 \\
\hline Mechanical engineering & 14 & 0 & 3 \\
\hline Total & 93 & 18 & 13 \\
\hline
\end{tabular}

the highest numbers. The 5 technical science majors are clearly below the average.

Table 4 shows the number of subjects without a recommended reading list for each major.

A lack of a recommended reading list for subjects is more common at the UC3M than in León or Salamanca. This is perhaps due to the greater work involved with entering it into a database which is mandatory at the University Carlos III. In general, this circumstance is more frequently found in elective subjects, the teaching of which depends on being chosen by a minimum number of students. There may be cases where these elective subjects have never been taught and, therefore, the syllabus avoids including any type of reading list.

Although it is not common to find subjects without a recommended reading list, incomplete ones are rather frequent. The elements most often omitted have to do with the edition and publication data but references were found without an author or a title. It is also quite rare for faculty to simply recommend class notes for the learning process instead of indicating resources which foster the students' autonomous learning as established in the European Higher Education Area (EHEA) (Martínez-González, 2010).

\subsection{Percentages of document types recommended as reference material}

Table 5 offers data on the types of sources most often used. The section "Other" includes rather uncommon document types such as reports, theses, standards, codes, official guides, commercial and product information, etc.

As can be observed in table 5, the recommended reading lists included in the syllabi are basically comprised of textbooks and specialized monographs which are the suggested learning materials. This predominance seems logical since students are beginning their educational process and require basic learning material at least in the first two years of a program.

The presence of links to websites, mainly at the USAL and, to a lesser extent, in Leon, is noteworthy. The UC3M, on the other hand, provides a lot lower number of links.

The scarce use in course syllabi of journal articles and, particularly, conference papers, is significant. We believe that reading lists are expanded when developing lessons; in fact, this is stated in some syllabi.

It is more common in some cases to recommend a certain journal title for consultation rather than a specific journal article. A total of 189 journals are referenced in the various recommended reading lists at the ULE.

The study by Lascuráin-Sánchez, Iribarren-Maestro, and Sanz-Casado (2008) already highlighted this predominance of monographs $(88.60 \%)$ and scarce presence of journal articles (7.41\%). Moreover, Liberatore's work (2007) focusing on South American universities reported 65\% monographs, $22 \%$ journal articles, and $5 \%$ electronic resources. The analysis more recently completed by Prieto-Paíno (2013) at the USAL makes it clear that paper monographs and textbooks, together, comprise $76.42 \%$ of the total references. Journal articles and journal titles are the following most recommended document types, but with a much lower incidence.

Table 6 shows the percentages of textbooks and monographs on all recommended reading lists.

The percentages of monographs are higher for technical science majors, mainly at the UC3M and ULE, as opposed to the USAL where this percentage is lower. Textbooks are obviously fundamental in engineering fields.

Table 5. Type of sources cited, by university

\begin{tabular}{|c|c|c|c|c|c|c|c|c|}
\hline \multirow{3}{*}{ Sources } & \multicolumn{8}{|c|}{ Universities } \\
\hline & \multicolumn{2}{|c|}{ Total } & \multicolumn{2}{|c|}{ UC3M } & \multicolumn{2}{|c|}{ ULE } & \multicolumn{2}{|c|}{ USAL } \\
\hline & No. & $\%$ & No. & $\%$ & No. & $\%$ & No. & $\%$ \\
\hline Journal articles and journal titles & 701 & 4.81 & 182 & 4.77 & 308 & 5.77 & 211 & 3.91 \\
\hline Book chapters* & 92 & 0.97 & 29 & 0.76 & 63 & 1.18 & -- & -- \\
\hline Papers/presentations for congresses & 47 & 0.32 & 13 & 0.34 & 23 & 0.43 & 11 & 0.20 \\
\hline Books & 12,327 & 85.36 & 3,432 & 90.10 & 4,473 & 83.93 & 4,422 & 82.05 \\
\hline Websites & 1,349 & 8.46 & 34 & 0.89 & 451 & 8.46 & 864 & 16.03 \\
\hline Other** & 97 & 0.89 & -- & -- & 11 & 0.20 & 86 & 1.59 \\
\hline
\end{tabular}

*only considered in the calculation for the universities UC3M and ULE

**only considered in the calculation for the universities ULE and USAL 
Table 6. Percentage of monographs by major and university

\begin{tabular}{|l|c|c|c|}
\hline \multirow{2}{*}{ Majors } & \multicolumn{3}{|c|}{ Universities } \\
\cline { 2 - 4 } & UC3M & ULE & USAL \\
\hline Business management & 84.52 & 80.75 & 76.63 \\
\hline Law & 83.67 & 77.83 & 77.56 \\
\hline Economics & 78.80 & 82.57 & 94.64 \\
\hline Information science & 78.87 & 88.29 & 77.67 \\
\hline Human resources & 89.08 & 70.46 & 77.37 \\
\hline $\begin{array}{l}\text { Total average for social } \\
\text { science fields }\end{array}$ & $\mathbf{8 2 . 9 8}$ & $\mathbf{7 9 . 9 8}$ & $\mathbf{8 0 . 7 7}$ \\
\hline Electrical engineering & 99.00 & 96.22 & 78.23 \\
\hline $\begin{array}{l}\text { Electronic and industrial } \\
\text { engineering and auto- } \\
\text { matic control }\end{array}$ & 99.00 & 88.81 & 79.94 \\
\hline Energy engineering & 100.00 & 95.19 & 92.37 \\
\hline Computer engineering & 97.80 & 92.02 & 85.44 \\
\hline Mechanical engineering & 99.00 & 95.20 & 87.61 \\
\hline $\begin{array}{l}\text { Total average for techni- } \\
\text { cal science fields }\end{array}$ & $\mathbf{9 8 . 9 6}$ & $\mathbf{9 3 . 4 4}$ & $\mathbf{8 4 . 7 1}$ \\
\hline
\end{tabular}

On the contrary, the percentages of monographs used for social science majors are not only considerably lower because other document types are used, but they are also more uniform among all of the universities. Less disparate trends are observed at the USAL between the social and technical science fields.

The percentages of monographs are always above $76 \%$ at the three universities analyzed and even reach $100 \%$, as is the case of the energy engineering major at the UC3M where the average for all technical majors is above $98 \%$, versus $84.71 \%$ at the USAL.

Links to institutional websites predominate whereas the presence of electronic books is residual despite a proven inclination to prioritize recommendations for monographs and textbooks

\subsection{Presence and weight of electronic documents}

The percentage of electronic resources at the UC3M is only $3.49 \%$ whereas it is $11.12 \%$ at the ULE and $16.12 \%$ at the University of Salamanca. Although the differences between the three universities are significant, it is obvious that the presence of electronic resources on recommended reading lists is currently quite marginal (table 7). The Prieto-Paíno study (2013) concerning the University of Salamanca obtained similar data referring to the presence of electronic resources in six degree programs, specifically $17.05 \%$.

Links to institutional websites predominate whereas the presence of electronic books is residual despite a proven inclination to prioritize recommendations for monographs and textbooks. The presence of electronic journals and electronic articles is also marginal. Prieto-Paíno's work (2013)
Table 7. Percentage of electronic documents by major

\begin{tabular}{|l|c|c|c|}
\hline \multirow{2}{*}{\multicolumn{1}{|c|}{ Majors }} & \multicolumn{3}{c|}{ Universities } \\
\cline { 2 - 4 } & UC3M & ULE & USAL \\
\hline Business management & $1.78(6)$ & $14.78(106)$ & $11.95(66)$ \\
\hline Law & $1,52(11)$ & $13.43(83)$ & $20.44(195)$ \\
\hline Economics & $0.54(2)$ & $16.24(96)$ & $29.85(106)$ \\
\hline Information science & $12.56(69)$ & $14.08(71)$ & $16.51(131)$ \\
\hline Human resources & $1.43(5)$ & $7.12(70)$ & $16.39(100)$ \\
\hline Electrical engineering & $0.87(2)$ & $6.68(23)$ & $8.54(33)$ \\
\hline $\begin{array}{l}\text { Electronic and industrial } \\
\text { engineering and automatic } \\
\text { control }\end{array}$ & $2.10(6)$ & $13.64(61)$ & $9.35(35)$ \\
\hline Energy engineering & $0.00(0)$ & $6.00(20)$ & $7.62(34)$ \\
\hline Computer engineering & $4.50(28)$ & $8.51(32)$ & $28.16(89)$ \\
\hline Mechanical engineering & $1.50(4)$ & $7.43(31)$ & $12.43(75)$ \\
\hline
\end{tabular}

corroborates this reality, indicating websites that include a variety of resources are the ones generally recommended. Furthermore, the author observed frequent recommendations for institutional sites, virtual campuses, and the university's own library. This situation was also observed in this study at the three universities.

Therefore, it is evident that traditional document types continue to be recommended. In the most recent management report for the year 2013, the UC3M library indicated that the recommended reading lists for students for their various subjects continue to be $95 \%$ comprised of printed books (UC3M, 2013); this figure is in line with the values presented.

Despite the disparity of the percentages obtained for the three universities, the distribution by majors reflects a higher number of electronic resources for economics majors at the USAL and the ULE ( $29.85 \%$ and $16.24 \%$, respectively) and in computers at the University of Salamanca (28.16\%). However, the advantage of using the collection of this type of resources at the UC3M is not appreciated; it is at least not reflected on the subject syllabi.

The inclusion of electronic resources for information science majors also stands out as it is similar at the three universities with an average of $14.32 \%$. The explanation has to do with the fact that this degree program trains students on searching, assessing, and using these types of resources; hence, the faculty is more aware of their usefulness. The fact that the UC3M and the ULE offer this major in a blended learning format and that the ULE has begun offering it online cannot be ignored ${ }^{3}$. We believe electronic resources are essential to these learning models.

The present situation differs from that found in the 20062007 academic year for the associate's degree in library and information science and the bachelor's in information science. At that time, the presence of electronic resources was scarcer at the ULE than at the other two universities studied (Lascuráin-Sánchez; Iribarren-Maestro; Sanz-Casado, 2008). We believe the blended learning format for the associate's degree and bachelor's in information science influenced the change at this university. 
As mentioned, the data that most stands out for all the majors offered at the UC3M are the 69 total references for the bachelor's in information science. The presence of $33 \mathrm{e}-$ books, 17 e-journals and 19 websites is noteworthy. Other than this degree program, only computer engineering reflects a significant figure at 28 references for websites. The data collected for all of the other majors show electronic documents are not significant. However, and despite the scarce references to e-books in syllabi, the most common use of e-books, as observed from the data from the library at this university (UC3M, 2013), is found in technical scientific and business textbooks from the Safari platform which is the one most commonly used by students.

The presence of e-books with 43 out of a total of 71 references for the bachelor's in information science at the ULE stands out. As far as e-journals, the business management major stands out (16). References to websites are common for all of the majors with an outstanding presence for social science majors.

At the USAL, at least a hundred references to electronic resources are suggested for 4 majors. First, there's the major in law with 195 references, then the major in information science with 131, followed by economics with 106 and human resources with 100 .

The number of e-books referenced is 24 for the bachelor's in information science in addition to 22 references to e-journals, 3 to papers for conferences, and 58 website links. In relation to the number of electronic documents, it is followed by the bachelor's in computer engineering (16 monographs) with a high number of links to software and application firm manuals. In general, there is a greater volume of links provided for majors in social science fields as opposed to those in technical science fields.

\subsection{Beginning and ending dates of the references}

It is worth mentioning that many of the bibliographic references lack dates, showing the poor widespread practice of referring to the most recent edition of the works, without specifying a year. This is a way faculty can avoid having to remain up-to-date on the newest editions available on the market.

Table 8. Beginning and ending dates on recommended reading lists

\begin{tabular}{|l|c|c|c|}
\hline \multirow{2}{*}{\multicolumn{1}{|c}{ Majors }} & \multicolumn{3}{c|}{ Universities } \\
\cline { 2 - 4 } & UC3M & ULE & USAL \\
\hline Business management & $1989-2013$ & $1981-2014$ & $1962-2014$ \\
\hline Law & $1872-2013$ & $1958-2013$ & $1960-2013$ \\
\hline Economics & $1970-2013$ & $1912-2013$ & $1970-2013$ \\
\hline Information science & $1963-2013$ & $1952-2013$ & $1946-2014$ \\
\hline Human resources & $1967-2013$ & $1959-2014$ & $1972-2014$ \\
\hline Electrical engineering & $1969-2012$ & $1968-2013$ & $1960-2010$ \\
\hline $\begin{array}{l}\text { Electronic and industrial } \\
\text { engineering and auto- } \\
\text { matic control }\end{array}$ & $1969-2012$ & $1970-2013$ & $1960-2010$ \\
\hline Energy engineering & $1969-2014$ & $1974-2013$ & $1963-2012$ \\
\hline Computer engineering & $1977-2013$ & $1970-2014$ & $1983-2014$ \\
\hline Mechanical engineering & $1967-2013$ & $1970-2013$ & $1960-2012$ \\
\hline
\end{tabular}

As for the recentness of the recommended works (tabla 8), current bibliographic references predominate. All of the subjects mostly suggest works published in the last decade of the 20th century and the years that have passed in the 21st. Prieto-Paíno's study (2013) corroborates this situation and indicates that nearly all of the bibliographic references provided at the USAL fall into the time period of 1990-2013.

The oldest publication dates correspond to social science majors where works are recommended for history-related subjects such as "Roman law", for example, with very early publication dates and editions even dating back to the end of the 19th century. The publication dates for engineering majors are more recent with the oldest dating back to the late 1960's or early 1970's. This is justified by the characteristics of these studies, some of which are particularly linked to information and communication technology (ICT).

\subsection{The suitability of reading list preparation}

Another aspect that could be observed when doing this research is the lack of standardization when preparing recommended reading lists. As already indicated, the number of incomplete references is quite high and the element most often omitted is the publication date of the resources. One malpractice was observed, as mentioned, which consists of asking for the most recent edition of the works without specifying a particular year.

In León, the recommended reading lists are incomplete for 132 subjects. With the exception of information science, business management and economics, partially incomplete references are provided for more than 10 subjects in all of the other majors. Incomplete references are provided for less than 10 subjects in the social science degree programs at the UC3M. The references at both universities are rather meticulous for the bachelor's in information science. This is likely because it is a major that educates future information professionals and the faculty are more committed to these aspects.

A significant number of subjects with partially incomplete references, particularly the publication information, was noticed at the USAL. As in the other two cases, the date is frequently omitted as can be seen with the bachelor's in electronic engineering where 22 references offer no date at all.

The data comprising the reading list references are entered at the UC3M using a template with fields which facilitate greater standardization in the bibliographic references. This may also be the reason why there are fewer references at this university than at the other two universities studied, as has been mentioned. This type of template also exists at the ULE which forces the completion of all essential data for bibliographic references, but its use is not mandatory, meaning recommended reading lists are not usually entered by means of this system.

\section{Conclusions}

There is no clear pattern of conduct as far as the number of references included in the recommended reading lists for the various majors at the different universities or for the subjects under the same degree program. The thoroughness 
of the recommended reading lists shows considerable variability. The only data worth mentioning is the lower number of references per major at the University Carlos III and the higher number of references for social science majors.

No significant differences were observed in the recommended reading lists between the first two years and the last two years of the degree programs as far as the type of sources, as was seemingly noticed in the United Kingdom (Housewright; Schonfeld; Wulfson, 2013b).

Books are the resources most frequently suggested in all of the curricula analyzed. This fact is understandable since syllabi generally only recommend reference works and textbooks which are valid for all or some of the classes and are aimed at students who are beginning their academic lives. Moreover, this is evidence that the trend is to suggest a bibliography to students which is connected to the traditional, consolidated curriculum and avoid a more current bibliography.

Likewise, there is an almost exclusive reliance to paper formats. As was indicated, library collections continue to be comprised of a very high percentage of printed books as can be deduced from the data provided in the most recent Rebiun annual corresponding to the year 2012, and in the library reports consulted.

Libraries have made significant efforts in recent years to subscribe to electronic content. It is true that most of the resources were initially related to experimental and medical science fields. Nonetheless, libraries have also subscribed to journal and book content packages in social and technical science fields such as Emerald, IEEExplore and Safari.

We believe it would be appropriate for faculty to use the collection of electronic resources their universities subscribe to because the libraries at these universities are investing more than $50 \%$ of their budgets in subscriptions to electronic journal and electronic book packages as deduced from the library reports.

Studies based on download statistics, some focusing on universities in the Spanish region of Castilla y León which use data from León and Salamanca, indicate that electronic journals are not, however, used as would be hoped (Rodríguez-Bravo; Alvite-Díez, 2006; Rodríguez-Bravo; AlviteDíez; Barrionuevo-Almuzara, 2012).

The research group of the University of Leon, Condor, since 2006 has been investigating the impact of e-journal collections in scholars' research in Spanish and Portuguese universities (Rodríguez-Bravo et al., 2012; Rodríguez-Bravo; Alvite-Díez, 2013; Rodríguez-Bravo; Melo; Costa, 2014). In this study we researched the impact of e-resources on teaching tasks and found is very limited.

To promote the use of e-resources, we would like to emphasize the need to diversify the document types in syllabi and to increase the presence of electronic resources that are openly accessible and subscribed to by the libraries. Universities in Spain do not offer many blended learning or online degree programs, yet the offerings in this area are increasing. Clearly an online degree program should facilitate access to the recommended reading list without the need to physically go to the university library. It would be beneficial for students and university budgets to choose electronic versions of the suggested documents when such an option exists.

A large part of the current debate surrounding electronic books focuses on the role of monographs in scientific dissemination and on whether they will remain in their privileged status in the academic world. Although there continue to be predictions alluding to libraries without books or with books merely as decorative objects, this situation has not generally proven to be reality. According to the recent Ithaka $S+R$ US Library Report (Long; Schonfeld, 2014), the transition to ebooks has not been as easy as expected. Most library directors report that the massive acquisition of e-books has not led to a similar decrease in the circulation of paper books.

\section{It would be advisable for all universities to use a database with fields that ensure the presentation in a standardized format}

Housewright, Schonfeld and Wulfson (2013a; 2013b) provided evidence that academics were quite happy to do away with paper versions of journals, although differences were found among the various fields. Humanities faculty were less enthusiastic about this possibility, followed by those in the social science fields.

With respect to electronic books, only about one third of academics still believed the electronic versions of research monographs played a significant role in their research and/ or teaching. Academics were somewhat more inclined to use them in the health sciences field. Furthermore, there was widespread mistrust in a future exclusively dominated by e-books. Even in science fields only $15 \%$ of all faculty interviewed proved to be enthusiastic about the possibility of doing away with the paper book collections within five years. On the contrary, only between 20 and $25 \%$ of library directors believed acquiring printed books is a high priority when it comes to building their collections. One year later (Long, Schofeld, 2014), American academics were placing less importance on maintaining printed collections locally.

The importance of books in teaching and their extensive use must force libraries to reflect upon the sums dedicated in their budgets to monographs and journals, the latter of which have been traditionally favored, and prioritize the research work done by faculty in an attempt to satisfy the needs of these academics over that of the students. The embedded librarian should promote in the academic communities the use of e-resources in order to establish, as Anglada (2014) pointed out, a new stereotype of the library based "on the role of support and assistance in the difficult process of using information and transforming it into knowledge".

It is our opinion that the current bachelor's degree programs, which have been adapted to the European Higher Education Area (EHEA), require more exhaustive recommended reading lists given that they foster more autonomous work by students. Notwithstanding, we believe it is necessary to make a clear differentiation between the core and supplementary sections of the lists and limit the for- 
mer to references to basic materials that are valid for all or a large portion of the classes. Our belief is that putting a limit on the number of references included is positive as it increases the consistency between the various subjects in the same major, facilitates the students' task of gaining a deeper understanding for the content and forces faculty to revise their recommended reading lists when they wish to add new documents to them.

In view of the lack of standardization in the preparation of reading lists, it would be advisable for all universities to use a database with fields that ensure the features presentation in a standardized format and all of the elements required to identify the resources. This situation is only effectively found at University Carlos III.

\section{The study shows that the recommended works are usually available at the corres- ponding libraries}

Faculty training on the use of bibliography writing standards needs to be emphasized as these standards are essential to the correct identification and recovery of the information. They also need to be trained on the use of bibliographic management systems as has been done at libraries in recent years.

For this research, we did not study purely scientific and medical-related majors which are fields that may show different trends and perhaps a greater inclination towards the use of electronic resources. It would be advisable to expand this study to majors not covered herein when doing further research.

It would also be interesting to check whether the recommended works in reading lists for the subjects are available or accessible via the corresponding libraries. We advocate a transparent and effective connection between the recommended reading lists and the discovery tool used for easy access to the suggested resources. This is already implemented in some universities as is the case of the University Politécnica of Valencia.

Prieto-Paíno's work (2013), which documents a series of interviews with USAL faculty, concludes there is no real concern for including electronic resources in recommended reading lists or for revising or updating the lists already created. Faculty are also not often concerned about verifying availability in the library collection. Nonetheless, the study shows that the recommended works are, in fact, usually available at the corresponding libraries.

\section{Notes}

1. The most recent Rebiun statistical annual available is for the year 2012.

http://www.rebiun.org/publicaciones/Paginas/AnuariosEstad\%C3\%ADsticos.aspx

2. The study carried out based on circulation data for the University of León collection (2012/2013 and 2013/2014 academic years) shows that students basically borrow textbooks and monographs (Condor research group).
3. The University of León began offering an associate's degree in library science and documentation in a blended learning format at the same time it did in the face-to-face format, in the 2006-2007 academic year. Ever since the 2010-2011 academic year, it has offered a bachelor's in information and documentation in this format and it began offering this major in a distance format for the 2014-2015 academic year. It is the only bachelor's program at the University of Leon offered in this format despite the more extensive distance master's offering.

The UC3M began offering the same bachelor's program in a blended learning format as of the 2008-09 academic year yet it had previously been offering the precedent to this major (associate's degree in library science and documentation) in this same format ever since the 2006-2007 academic year. The UC3M offers 3 university master's programs in a blended learning format as well.

\section{Bibliography}

ACRL (2015). Environmental scan 2015. By the ACRL Research Planning and Review Committee, March 2015. Chicago: Association of College and Research Libraries. http://www.ala.org/acrl/sites/ala.org.acrl/files/content/ publications/whitepapers/EnvironmentalScan15.pdf

Anderson, Renee-Nesbitt (1988). "Using the syllabus in collection development". Technicalities, v. 8, n. 1, pp. 14-15.

Anglada, Lluís (2014). "Are libraries sustainable in a world of free, networked, digital information?". El profesional de la información, v. 23, n. 6, pp. 603-611.

http://www.elprofesionaldelainformacion.com/contenidos/2014/ nov/07.pdf

http://dx.doi.org/10.3145/epi.2014.nov.07

Anglada, Lluís (2012). "Bibliotecas universitarias: cabalgando la tecnología, siguiendo al usuario". El profesional de la información, v. 21, n. 6, pp. 553-556.

http://www.elprofesionaldelainformacion.com/ contenidos/2012/noviembre/01.pdf

http://dx.doi.org/10.3145/epi.2012.nov.01

Austenfeld, Anne-Marie (2009). "Building the college library collection to support curriculum growth". Collection management, v. 34, n. 3, pp. 209-227.

http://dx.doi.org/10.1080/01462670902975027

Dilek-Kayaoglu, Hulya (2008). "Use of electronic journals by faculty at Istanbul University, Turkey: The results of a survey". The journal of academic librarianship, v. 34, n. 3, pp. 239-247.

http://dx.doi.org/10.1016/j.acalib.2008.03.007

Gomez-Yáñez, José-Antonio (coord.) (2014). The economic and social value of information services: Libraries. Madrid: Fesabid.

http://www.fesabid.org/documentos/economic_social_ value_information_service_libraries.pdf

Hernández-Sánchez, Hilario; Arroyo-Vázquez, Natalia (2014). "Efectos de la crisis económica en las bibliotecas españolas". El profesional de la información, v. 23, n. 2, pp. 158-164. 
http://eprints.rclis.org/22806

http://dx.doi.org/10.3145/epi.2014.mar.08

Housewright, Ross; Schonfeld, Roger C.; Wulfson, Kate (2013a). Ithaka S+R US Faculty survey 2012. Ithaka S+R, April 8.

http://www.sr.ithaka.org/wp-content/uploads/2015/08/ Ithaka_SR_US_Faculty_Survey_2012_FINAL.pdf

Housewright, Ross; Schonfeld, Roger C.; Wulfson, K. (2013b) Ithaka S+R, Jisc, RLUK, UK Survey of academics 2012. Ithaka S+R, May 16.

http://www.rluk.ac.uk/wp-content/uploads/2014/02/UK_ Survey_of_Academics_2012_FINAL.pdf

Lascuráin-Sánchez, María-Luisa; Iribarren-Maestro, Isabel; Sanz-Casado, Elías (2008). "Análisis de la bibliografía recomendada en los planes de estudio de las diplomaturas en biblioteconomía y documentación y las licenciaturas en documentación de las universidades españolas". En: Frías, José-Antonio; Travieso, Críspulo (eds.). Formación, investigación y mercado laboral en información y documentación en España y Portugal. Salamanca: Ediciones Universidad de Salamanca, pp. 813-825.

Liberatore, Gustavo (2007). "El análisis documental desde la perspectiva bibliográfica en los cursos de formación de grado de Mercosur: una aproximación bibliométrica". Revista de historia de la comunicación, v. 8, n. 5.

http://eprints.rclis.org/11854

Long, Matthew P.; Schonfeld, Roger C. (2014). Ithaka $S+R$ US Library Survey 2013. Ithaka $S+R$. Ithaka S+R.

http://www.sr.ithaka.org/wp-content/uploads/2015/08/ SR_LibraryReport_20140310_0.pdf

McDonald, Joseph; Micikas, Lynda-Basney (1990). “Collection evaluation and development by syllabus analysis: The must-ought-could (MOC) method". In: Genaway, David C. (ed.). Acquisitions'90: Conference on acquisitions, budgets and collections (May 16 and 17), pp. 289-316. Canfield, $\mathrm{OH}$.

Martínez-González, José-Alberto (2010). “El Espacio Europeo de Educación Superior (EEES) y nuevo rol del estudiante universitario". Cuadernos de educación y desarrollo, v. 2, n. 16. http://www.eumed.net/rev/ced/16/jamg.htm

Prieto-Paíno, Cristina (2013). Tipología, características y género de las bibliografías recomendadas: el caso de humanidades, ciencias sociales y especialidades científico-técnicas en la Universidad de Salamanca. TFG realizado bajo la dirección de José-Antonio Cordón-García. Salamanca: Universidad de Salamanca.

Rodríguez-Bravo, Blanca; Alvite-Díez, María-Luisa (2006). "Uso de las revistas-e suministradas por Emerald en bibliotecas universitarias españolas (2002-2005)". El profesional de la información, v. 15, n. 6, pp. 464-472.

http://www.elprofesionaldelainformacion.com/contenidos/2006/ noviembre/08.pdf
Rodríguez-Bravo, Blanca; Alvite-Díez, María-Luisa; Barrionuevo-Almuzara, Leticia (2012). "Trends and models in the consumption of electronic contents. An analysis of the journals most widely used in Spanish universities". Journal of academic librarianship, v. 38, n. 1, pp. 42-59. http://dx.doi.org/10.1016/j.acalib.2011.11.007

Rodríguez-Bravo, Blanca; Alvite-Díez, María-Luisa; MoránSuárez, María-Antonia; Marraud, Gerardo (2012). “Impacto de la contratación de colecciones de revistas electrónicas en la productividad de la Universidad de Vigo". El profesional de la información, v. 21, n. 6, pp. 585-594. http://dx.doi.org/10.3145/epi.2012.nov.05

Rodríguez-Bravo, Blanca; Borges, Maria-Manuel; Fernandes, Alberto N. O.; Olea, Isabel; De-Oliveira, Maria-JoãoCarvalho (2013). "Hábitos de consumo y satisfacción con las revistas electrónicas de los investigadores de las universidades de Coimbra, León y Porto". In: Globalização, ciência, informação. VI Encontro Ibérico Edicic 2013: 4-6 de noviembre. Porto: Universidades do Porto, Faculdade de Letras: Cetac.Media, pp. 1189-1208.

http://eprints.rclis.org/23189

Rodríguez-Bravo, Blanca; Melo, Luiza-Baptista; Costa, Teresa (2014). "Impact of the consumption of electronic contents on research productivity in some Portuguese and Spanish university" Qualitative and quantitative methods in libraries (QQML), v. 3, pp. 601-611.

http://goo.gl/eglzlv

Shirkey, Cindy (2011). "Taking the guesswork out of collection development: Using syllabi for a user-centered collection development method". Collection management, v. 36, n. 3, pp. 154-164.

http://dx.doi.org/10.1080/01462679.2011.580046

Tenopir, Carol; King, Donald W. (2000). Towards electronic journals: Realities for scientists, librarians and publishers. Washington: Special Libraries Association.

University Carlos III of Madrid (2013). Biblioteca. Memoria de actividades 2013.

http://e-archivo.uc3m.es/bitstream/handle/10016/19631/ memoria_biblioteca_2013.pdf?sequence $=1$

University of León (2013). Uso de los recursos electrónicos. Informe 2013. León: Universidad de León, Biblioteca.

University of León (2014). Uso de los recursos electrónicos. Informe 2014. León: Universidad de León, Biblioteca.

University of León (2015). Condor (Organización y uso de contenidos digitales).

http://www.unileon.es/grupos-investigacion/detallesgrupo.php?id=0\&grp=163

Urbano, Cristóbal (2000). “Tipología documental citada en tesis doctorales de informática: bases empíricas para la gestión equilibrada de colecciones". BiD: Textos universitaris de biblioteconomia i documentació, n. 5, desembre.

http://bid.ub.edu/05urban2.htm 